\title{
Constitutional Implications of Medical Action Refusal by Pediatric Patient's Parents
}

\author{
Unggul Hudoyo $^{1}$, Yusufa Ibnu Sina Setiawan ${ }^{2}$, Mokhammad Najih $^{3}$ \\ \{unggul.advokat@gmail.com ${ }^{1}$, yusufaibnusina92@gmail.com², najih@umm.ac.id ${ }^{3}$ \} \\ ${ }^{1}$ Master of Law Study Program, Universitas Muhammadiyah Malang, Indonesia
}

\begin{abstract}
The law recognizes qualified adult patients to have right in refusing or accepting medical treatments, even if the refusal may cause fatal risk. In the other hand, for pediatric patient, the parents are the one who responsible for their medical treatment agreement. This phenomenon puts the child in a difficult situation as well as raises ethical and professional dilemmas for the doctors. This research aims to reveal the problem faced by pediatric patients in obtaining health right, health services specifically. The research type conducted is normative juridical. As a consideration, the research started by analysing laws and regulations to identify legal concepts and principles used in regulating children's rights. Thus, the approaches taken are the statutory approach and the conceptual approach. Research result shows that the child's health rights are guaranteed by child rights convention and regulation concerning child protection, Law Number 23 Year 2002 which revised into Law Number 35 Year 2014. However, refusal of medical treatment by pediatric patient's parent has no specific legal consequences. As the research recommendation, to legally protect children's health rights, the government should formulate specific regulation for pediatric patient's parent. So that, they can be legally accused when they refuse medical treatment that important for children health interest.
\end{abstract}

Keywords: Children's Health Rights; Patient's Parents: Medical Treatment.

\section{Introduction}

Basically, human live needs the laws. Along the history, the law has a central role to make humans feel protected, live side by side in peace and keep their existence recognized [1]. The dependence of human life on law is confirmed through literature, from classical law era to the postmodern era. Similarly, law also has a strategic role in the health field, especially in the relationship among doctors and patients.

Relationships between doctors and patients categorized as personal relationship due to their trust to the doctors. Wilson depicts the relationships as personal as relationship between the priest and the congregations who was expressing their feeling [2]. Personal recognition is very important for self-exploration and requiring protected conditions in the private consultation room. In receiving medical treatment, patients will disclose their confidential information to the doctor. Patients have strong reason to trust and entrust themselves to the doctors because doctor has been declared as a professional [3].

Recently the relationship pattern has change from vertical paternalistic becomes contractual horizontal (contract relationship). Patients visit is considered as receiving help offers for the health complaints, and vice versa for the doctor who provides help in accordance with the medical science. This contractual relationship occurs because of the patient's trust toward the doctor's knowledge and ability to help patient's health complaints [4]. Patients need help with their unknown disease and rest their hopes on a doctor who has the knowledge. Position of the patient is weaker than the doctor and they are vulnerable to unfair actions. Therefore, doctors have an obligation to always respect 
patients' rights related to decisions making process toward taken medical actions.

The relationship between the patient and the doctor is categorized as therapeutic relationship. In legal point of view, the relationship qualified as agreement-based engagement. The therapeutic agreement between a patient and a doctor created to provide health services based on the doctor's expertise [5]. Through this agreement, the rights and commitments of each party will appear to obtain certain goals desired by patients from medical services provided by doctors. However, it should be noted that the therapeutic contract is not an agreement based on results (resultaatververbintennis) but categorized as engagement based on maximum effort (inspanningverbintennis) [6].

In health services, patients as receiver and doctors as provider have equal rights and obligations and must respect each other. Problems often found in this relationship usually related to medical treatment approval. Generally, common people consider signed form before undergoing a surgery is just a formality. Obtaining patient consent before medical treatment, including pre-surgery is an essential part of current health care system. Achieving informed consent or "approved medical action" run as a patient's autonomy guarantee in right to self-determination and is seen as good practice in health care.

The Oxford English Dictionary defines, "Consent" as "voluntary agreement to, or acquiescence in, what another proposes or desire; compliance, concurrence, permission". Informed consent is free assent given by the patient for medical action, since the patient gets all significant information about the nature and consequences of the action [7]. The form is very important to determine medical actions validity carried out by medical personnel (doctors). In Indonesia, Informed consent in health services has been legitimately defended through Minister of Health Regulation Number 585/Menkes/Per/IX/1989 concerning Approval of Medical Measures. Afterward, it changed into Indonesian Minister of Health Regulation Number 290/Menkes/Per/III/2008 concerning Approval of Medical Measures. Medical actions without the patient's assent can bring about criminal allegations to the doctors for supposed maltreatment, as accommodated in Article 351 of the Indonesian Criminal Code. However, if the patient experiences an emergency condition informed consent is not needed in order to save patient's life [8].

In the other hand, there is also medical action rejection statement letter named "informed refusal". Rejection of medical treatment is the patient's right to determine what he wants to do to himself and is done after obtaining information from a doctor [9]. The act of giving consent or rejection to the future medical action is entirely the patient's right [10]. The law recognizes qualified adult patients to have right in refusing or accepting medical treatments, even if the refusal may cause fatal risk. In the other hand, for pediatric patient, the parents are the one who responsible for their medical treatment agreement.

Informed consent submission can only be given to patients who have the ability to accept and can understand doctor explanations. In general, the steps for granting informed consent are as follow [11]:

a. The doctor provides accurate and complete information about the patient's medical condition, type, nature and purpose of the action, as well as the risk of the taken action;

b. The doctor believes that the information has been understood by the patient;

c. Doctors ensure that patients are able to make decisions;

d. Doctors believe to the extent possible that patients provide decisions without coercion or manipulation.

By examining each part of the informed consent form, parents or guardians of pediatric patients who will sign the form are expected to comprehend the information gave by the doctor. Moreover, if in the future a problem related to a patient's health is found, the informed consent form can be presented as evidence in court.

Legally, all risks that may occur from medical treatment must be honestly conveyed to the parents of pediatric patients. They may refuse medical treatment even though the child really needs it and if not done immediately will cause fatal impact and can threaten the survival or cause disability of children. On the other hand, doctors are required to respect pediatric patients' parents' autonomy 
rights in approving medical measures. This is what puts children in difficult situations and raises ethical, legal and professional dilemmas for the medical profession.

By defacto, children are separate individuals from their parents. They possess equal rights with adults, including Human Rights. Doctors and parents cannot deny a child's rights. If a father or mother takes the child to the doctor, the patient is the child, not the parents. Therefore, pediatric patients must be the primary consideration and become the main responsibility of the doctors [12]. The children's rights are stressed by the General Explanation of Law No. 23 of 2002 concerning Child Protection. It expresses that in the point of view of human rights, children's rights are included [13]. Child rights are likewise human rights contained in the 1945 Constitution of the Republic of Indonesia and the UN Convention on the Rights of the Child [14].

\section{Method}

The research method utilized in this paper is the normative legal research method, using the statute approach and conceptual approach. Statute approach is based on legal regulations review related to the problem discussed. These legal regulations become the primary legal material in this study. The conceptual approach will provide understanding by quoting legal experts opinions. This paper is written based on the previous studies' results, so that the problem will be analyzed more comprehensively. Deduction reasoning is used to solve specific problems.

\section{Results and Discussion}

\subsection{Relationship between Doctors and Patients}

The doctor and patient relationship basically lays on two kinds of human rights, in particular the right to self-determination and the right to information [15] as pedestal of the right to health care. Despite the fact that the right to health care and the right to self-determination are fundamentally equivalent, the second rights is viewed more essential since it contains privacy rights of their body [16].

Strictly Article 3 of the 1948 Declaration of Human Rights expresses that "Everyone has the right to life, liberty and security of individual." Therefore, there is an assurance that everybody has the right to life, freedom and personal security [17]. As the outcome, no activity is allowed against these rights. The doctor's activities towards patients depend on the principle of "equality before the law". Everyone, including doctors, has a comparable circumstance under the law. Besides, in the field of medical services patients must not be forced by anyone, both mentally and physically, to accept or dismiss the proposed medical actions. Doctors who will conduct medical treatment on patients must get their assent as the proprietor of the body, medical actions without the patient's assent are seen as ignoring the law or the rights of the patient.

In Indonesia, human rights in the health sector have been directed in the 1945 Constitution of the Republic of Indonesia, especially Article 28H section (1) which states:

Each person has the right to live in prosperity physically and intellectually, to live, to have a healthy environment and receive health services.

And Article 34 paragraph (3) which states:

The state is responsible for the provision of adequate health service facilities and public service facilities.

Besides, Indonesia has also stipulated Law Number 36 Year 2009 regarding Health as an effort to advance national welfare related to health and to protect Indonesian from violation related to health [18]. From a Civil law perspective, doctors who obtained a Registration Certificate (Surat Tanda Registrasi) and a Practice License (Surat Izin Praktik) are considered to have made a public offering (openbare aanbod) if they have opened a practice and installed a name sign. If the offer is accepted or approved by another party, an engagement is made. Article 45 Paragraph (1) and Paragraph (2) of Law Number 29 Year 2004 concerning Medical Practices expresses that in order to make a legal agreement between the patient and the doctor, the offer must be followed by a 
complete doctor's explanation regarding diagonosis, treatment and prognosis as well. as a matter related to the patient's illness. If the patient agrees and wants to take medication, then a legal agreement between them takes place, known as a therapeutic contract [19].

The doctor and patient relationship are legal engagement based on agreement (verbintenis). Quoting Article 1313 jo. 1234 Civil Code, agreement is actions of one legal subject (person or body) or more, commit oneself to one or more legal subjects (person or body), to do something and/or not to do something called performance (prestasi). Performance itself described as the legal obligations of each party which carries out a legal engagement. Thus, therapeutic contracts as legal engagement between doctors and patients require give and take each other performance [20].

The basic performances that doctors must give to patients in a therapeutic relationship consist of healing and prevention efforts, medical measures solely for the benefit of the patient's health. Performance is measured when actions are carried out optimally (inspanning) or not taking the necessary actions. Mainly based on medical professional standards and the standard operating procedures outlined in Article 50 of Law Number 29 Year 2004 concerning Medical Practices [21].

On the other hand, patients as recipients of medical services must participate and try as much as possible to recover. Without their involvement, doctor's medical efforts will not achieve the expected results. If the patient acts uncooperatively in their recovery and disobeying the doctor's instructions, their action categorized as contributory negligence and cannot be justified by the doctor [22].

Citating Hermien Hadiati Koeswadji [23], "Therapeutic transactions are agreements (Verbintenis) to find or determine the most appropriate medical treatment for patients by a doctor." While Veronica Komalawati stated that, "Therapeutic transaction is a legal relationship between doctors and patients in a professional medical service, based on competencies that are in accordance with certain expertise and skills in the medical field" [24]. Therefore, therapeutic transactions are clearly more specific agreement compared to general agreements, in example:

a. The subject of therapeutic transactions consists of doctors and patients. The doctor is a service provider who has certain qualifications and authority as professionals in the medical field who are competent to provide the assistance needed by patients. Whereas patients are parties who do not have the qualifications and authority as doctors, and are those who need the help of doctors who are obliged to provide honoraria for services provided by doctors;

b. The object of a therapeutic transaction is a professional medical procedure that has the characteristic of providing help;

c. The purpose of therapeutic transactions is maintenance and improvement of familyoriented health, including promotive, preventive, curative, and rehabilitative activities to realize optimal health [25].

Therefore, therapeutic transactions are a special engagement form that has inspanningverbintenis legal relationships, the legal principles and conditions that underlie the agreement must be fulfilled in a therapeutic transaction. The principles of therapeutic transactions according to Veronica Komalawati are as follows [26]: 
a. Principle of Legality

Derived from Article 50 of the Health Act, health workers are tasked with organizing health activities in accordance to their area of expertise and authority. This implies that, competent health services both education and licensing are in accordance with statutory provisions.

b. Principle of Balance

Health services must be done in a balanced manner, between individual and community interests, between physical and mental, between goals and facilities, between facilities and outcomes, between benefits and risks arising from medical efforts undertaken.

c. Principle of On Time

This principle is very important for health servants, especially doctors. Delay and negligence in handling the patient will be fatal and contrary to this principle. The speed and accuracy of handling patients is an important factor in supporting patients' recovery.

d. Principle of Good Faith

This principle is based on the principle of good deeds (kindness) that should be applied in the commitments of doctors to patients. As professionals, in applying this principle doctors need to respect the rights of patients in doing medical practice as well as uphold their professional standards.

e. Principle of Honesty

Honesty between doctors and patients is one of the important things in therapeutic transactions. Because the patient's position in the therapeutic transaction is very passive and very dependent on the doctor (vertical paternalistic).

According to Zaeni Asyhadie, the legal requirements for agreements relating to therapeutic transactions are regulated in Article 1320 of the Civil Code as follows [27]:

a. Conditions concerning agreement between parties who bind themselves to each other (toesteming van de genen die zichverbiden)

Agreement in therapeutic transactions for certain medical measures requires informed consent.

b. Conditions concerning party's ability to make a commitment (debekwaamheid om eene verbintenis aan te gaan)

According Article 1329 Civil Code, every person has the authority to make an agreement, unless he is declared incompetent for that matter. Meanwhile, those who are not permitted to enter into agreements based on Article 1330 of the Civil Code are:

i. Minors, a child who has not yet reached the age of majority;

ii. Person placed under guardianship;

iii. Married women if determined by law and generally anyone who by law is prohibited from entering into certain agreements.

c. Conditions concerning certain topic (een bepaald onderwerp)

Certain topic related to legal object or thing agreed. In a therapeutic agreement, "certain topics" are medical actions which performed by the doctors, namely the treatment and cure of an illness.

d. Conditions concerning permissible cause (een geoorloofdeoorzaak)

Agreement object must be in accordance with the law, public order and morality. For example, in a therapeutic agreement a doctor prohibited to conduct abortion without medical indication because it is against the law.

Thus, when the therapeutic transaction has fulfilled those legal conditions, obligations arising from the therapeutic transaction shall binding the parties, both the doctor and the patient. According to book III of the Civil Code which regulates engagement, there are two types of agreements:

a. Inspaningverbintenis, an effort agreement, meaning that both parties pledge to make maximum efforts to realize the agreement.

b. Resultaatsverbintenis, the party who promised must give the real result according to the agreement (resultaat) [28]. 
In therapeutic transaction, performances that doctor must provide to the patients consist of healing efforts and prevent medical action solely for patient's health interests. The performance measured when the action is done optimally (inspanning) or not performing required actions. Therefore, when doctors do not make the best effort to cure patients according to their professional standards, it has fulfilled the qualification as a default as regulated in Article 1239 of the Civil Code.

Besides, Doctor's wrongdoing in providing medical service achievements that cause civil loss to patients is qualified as malpractice. Physical health and the lives of patient loss as the result of doctor mistreatment become essential element of medical malpractice from civil and criminal law point of view [29].

\subsection{Approval of Medical Treatment (Informed Consent)}

The progress of informed consent in Indonesia was marked by an official statement from the Indonesian Doctors Association (IDI) through PB-IDI Decree Number 319 / PB / A.4 / 88 of 1988 concerning Informed Consent. After that, it was confirmed by Minister of Health Regulation Number 585 / Men.Kes / Per / IX / 1989 regarding approval of Medical Measures, which was later amended by Number 290 / Menkes / Per / III / 2008. In fact, long before the regulation existed, Indonesian health professionals have recognized and implemented it as a habit during operative actions and before performing surgery, in the form of written consent by the patient or his family [30].

Informed Consent composed of two words, informed which means they have received an explanation (information). Consent means approval or giving permission. In short, informed consent is consent given after obtaining information. For this reason, informed consent can be defined as the consent given by the patient or his family on explanation of medical actions taken against the patient as well as the risks that may arise. Every medical action taken must prioritize patient's health and there must be no coercion [31].

Based on Chapter I item Id Decree of the Medical Services Director General Number: HK.00.063.5.1866 concerning Informed Consent on 21th April 1999 stated that: in medical profession, Informed consent is a statement of assent or authorization from a patient that is given without forced by anyone, rationally, without coercion (voluntary), about the medical actions that will be carried out against him, after getting enough information [32].

Minister of Health Regulation No. 290 / Menkes / Per / III / 2008 concerning Approval of Medical Measures, provides a definition of informed consent as approval of medical actions by patients or immediate family, after getting a careful explanation of the actions of the doctor or dentist to be performed on the patient [33]. Sofwan Dahlan explains informed consent as unilateral statement from the rightful person (patient, family or guardian) containing doctor permission or approval to perform medical action after the rightful person receives sufficient information [34]. While Achmad Busro states that informed consent is a patient consent (or entitled family) for the doctor to take medical action on him, after complete explanation on the medical action taken is given [35].

There are two fundamental human rights that become the basis in informed consent, namely the right on information and the right on self-determination. According to Sofwan Dahlan, those rights are called ethical and moral principles and patient autonomy which contains two important things, namely:

a. Everyone has the right to decide freely what they will choose based on adequate understanding;

b. The decision must be made in possible circumstances to make a choice without interference. Because individuals are autonomous, information is needed to hold considerations in order to act in accordance with their considerations [36].

For service provider (doctor) and the user (patient) of medical treatment services, informed consent aims to legally protect the patient from illegal medical actions as well as to protect patients 
from arbitrary services. Namely, actions that are contrary to the patient's human rights and Medical Professional Standards, as well as unnecessary and over utilization examination which using highly costs sophisticated tools without any medical reason. Besides, informed consent can also protect the doctor from patient's lawsuit if the medical actions results were not satisfying [37]. Thus, informed consent is important before doctors take medical action.

However, in an emergency circumstance, doctors can take medical measures or extra medical measures without prior approval for spare lives. Article 4 passage (1) Regulation of the Minister of Health Number 290 / Menkes / Per / III / 2008 concerning Approval of Medical Measures and in the Provisions of Article 45 section (1) of Law no. 29 of 2004 concerning Medical Practice: "In an emergency to spare a patient's life, approval isn't required". After medical treatment is done and an emergency can be avoided, the composed assent must be submitted [38].

For example, patients as victims of traffic accidents were brought to the emergency room in an unconscious and critical condition. Patients need immediate help and there was no time to contact their families for medical treatment approval. Medical action must be taken immediately to save patient life, so that informed consent is not an urgent matter. Therefore, in an emergency situation the the patient is presumed to approved medical procedure (presumed consent). In emergency conditions, doctors must immediately take action life-saving or limb-saving without prior permission from the patient and his family. In these conditions, the speed of saving lives becomes a priority [39].

\subsection{Refusal of Medical Action (Informed Refusal)}

As individuals who are competent, knowledgeable, and free, patients can give and refuse medical treatment approval. As stated in the Patient's Bill of Rights, the patient has the right to refuse treatment to the extent permitted by law, and to be notified of the medical consequences of his actions. [40]. What's more, Article 19 of the Universal Declaration of Human Rights and Article 14 of Law Number 39 of 1999 concerning Human Rights expresses that everyone has the right to get information. The Decalration of Lisbon also mentioned the rights of patients, including the right to self-determination by accepting or rejecting future treatment after getting adequate and understandable information [41]. Law No. 29/2004 concerning Medical Practice Article 52.d states that in medical practice, patients have the following rights:

a. Obtain a complete description of medical treatment as referred to in Article 45 paragraph (2);

b. Ask another doctor or dentist for another opinion;

c. Getting services according to medical necessities;

d. Deny medical treatment;

e. Getting the contents of the medical record.

With the international and national provisions mentioned above, patients reserve the right to decline medical treatment subsequent to acquiring sufficient information. The consequences of rejection must be understood and be the responsibility of the patient. Such rejection is permissible as long as the patient's health condition does not interfere with others. The decision to accept or reject medical care is entirely the patient's right. If the patient uses the right to refuse medical treatment, he is deemed to have waived his legal rights against the doctor if an unwanted condition arises. [42].

Rejection of medical treatment is referred as the patient's right to obtain alternative medical treatment. This right become the expression of the right of self-determination. With the patient's right to refuse medical treatment, doctors must not force patients to accept certain medical actions. But the doctor is obliged to explain the risks or possibilities that would occur if the medical action was carried out. If after the patient receives an explanation he still refuses, then the patient must sign the refusal statement [43]. 


\subsection{Position of Pediatric Patients in Therapeutic Transactions}

There are differences in the definition of children in several regulations in Indonesia. Article 1 number 1 of Law Number 23 Year 2002 concerning Child Protection, validates a child as someone who has not been approved for 18 years and includes a child who is still in the womb. According to Article 1 number 5 of Law Number 39 Year 1999 concerning Human Rights, a child is someone who is under 18 years old and not married, including a child in the amount according to his interests. Under the International Covenant on the Rights of the Child, a child is anyone who agrees to be under the age of 18, except under the law applicable to children, which is determined based on the age of an adult who was previously obtained [44].

Even though a child's organs are the same as an adult's, their organ functions are not yet fully developed. So that health science is closely relating with child development. Infants and young children have not been able to provide consent [45]. In therapeutic transactions, patients as recipients of medical services can be anyone, whether they are capable or not. It is important for the doctors to note, as one of the parties who commit themselves in a therapeutic transaction, so as not to cause problems later on [46].

As indicated by Article 1329 of the Civil Code, each citizen is allowed to make an agreement, except if he is proclaimed incompetent as expressed in Article 1330 of the Civil Code. Be that as it may, in view of Article 1 passage 7 of the Minister of Health Regulation No. 290/Menkes/Per/III/2008 concerning Approval of Medical Measures, competent patients are:

Adult or non-child patients according to statutory regulations or have/have been married, have no disturbed physical awareness, able to communicate naturally, do not experience a setback (mental retardation) and mental illness thus able to make free decisions.

Therefore, child is incompetent in making engagement. In a therapeutic transaction, the pediatric patient cannot approve or reject the medical treatment independently. Thus, the decision-making process between accepting or rejecting a medical action taken is represented by parent or legal guardian. In more detail, this has been regulated in Decree of the Director General of Medical Services No. HK.00.06.3.5.1866 concerning Guidelines for Approval of Medical Treatment.

\subsection{Legal Implications in Refusing Medical Actions by Pediatric Patient's Parents}

Before conducting medical treatment, doctors must obtain patient approval, as regulated in Minister of Health Regulation No. 290 / Menkes / Per / III / 2008 concerning approval of medical treatment. Because the child patient is not competent to make an agreement, the decision to refuse or accept medical treatment is represented by a close family member. More specifically, father or mother, siblings or guardians. In the Minister of Health Regulation No. 290 / Menkes / Per / III / 2008 regarding approval of Medical Measures, there are no strict sanctions for parents who refuse medical treatment for their children. Ideally, approval of medical treatment should be done with the consent of children based on the principle of non-discrimination, the best interests of the child, the right to life, survival and development, and respect for the opinions of children. The principle of the best interests of children is the spirit of Law Number 35 of 2014 concerning Amendments to Law Number 23 of 2002 concerning Child Protection (Explanation of Law Number 35 of 2014 concerning Amendments to Law Number 23 of 2002 concerning Child Protection).

In light of Article 8 of Law Number 23 of 2002 as changed by Law Number 35 of 2014, parents have duties regarding children's health: "Each kid has the right to get health and social security services as per physical, mental, spiritual and social needs." what's more, Article 26 passage (1) of Law Number 35 Year 2014 concerning Amendments to Law Number 23 Year 2002 concerning Child Protection, parents additionally have responsibilities and obligations to their kids, specifically:

a. Encouraging, teaching and ensuring youngsters

b. Develop kids as indicated by their capacities, talents, and interests; 
c. Avoid child-age marriages; and,

d. Provide character education and teach the value of courtesy.

Parents are also obliged to keep up health and care for children, as regulated in Article 45 of Law Number 35 Year 2014 concerning Amendments to Law Number 23 Year 2002 concerning Child Protection, which states:

a. Parents and families are responsible for caring and maintaining children health since in the womb.

b. In the event that parents and their families can't do the obligations alluded to in paragraph (1), the central government and local governments must fulfill them.

c. The commitment alluded to in paragraph (2) is done as per the provisions of the legislation.

The right to self-determination as referred to in Article 52.d of Law Number 29 of 2004 concerning Medical Practices gives patients the right to refuse medical treatment. Juridically, parents of pediatric patients can refuse medical actions to be taken for their children and that is not against the law. Even so, there are criminal sanctions against child violence that cause physical suffering, as determined in Act Number 35 of 2014 concerning Amendments to Law Number 23 of 2002 concerning Child Protection. Furthermore, Law No. 23/2004 concerning the Elimination of Domestic Violence identified with the relationship of parents and children in the family also decided:

a. Acts against someone that results in physical misery or suffering including domestic violence (Article 1 paragraph (1)). These acts are classified as physical violence that is causing pain, falling ill, or serious injury (Article 6 jo. Article 5.a). The criminal sanction is a maximum a prison sentence of 5 (five) years or a maximum fine of Rp. 15,000,000.00 (Article 44 paragraph (1)).

b. Everyone is forbidden to neglect people within the scope of his household. According to applicable law or because of an agreement or agreement, he is obliged to give life, care, or care to that person (Article 9 paragraph (1)). Criminal sanctions are imprisonment for a maximum of 3 (three) years or a maximum of Rp. 15,000,000.00 (Article 49.a).

Therefore, if medical action refusal results in physical misery to the child, parents of pediatric patients considered as neglecting the children and can be prosecuted criminally. As mentioned in Article 76C:

Everyone is precluded from putting, letting, submitting, requesting or taking an interest in savagery against youngsters.

Article 1 paragraph (15a) of Law Number 35 Year 2014 concerning Amendments to Law Number 23 Year 2002 concerning Child Protection defines violence against children as:

Violence is an action against a child which results in physical, psychological, sexual, and / or neglect or suffering, including threats to take action, coercion or deprivation of liberty that violates the law.

Then, Article 80 section (1) of Law Number 35 Year 2014 concerning Amendments to Law Number 23 Year 2002 concerning Child Protection specifies that:

Every person who violates the provisions as referred to in Article 76C, shall be sentenced to a maximum imprisonment of 3 (three) years 6 (six) months and/or a maximum fine of Rp. 72,000,000 (seventy-two million rupiahs).

As a study case, neglect within the scope of the household is contained in the Sumbawa District Court Decision Number 113/Pid.B/2014/PN.Sbb. The defendant abandoned and did not financially support his family so that the child got sick.

In its decision, the Panel of Judges concluded that the litigants were legally and convincingly demonstrated responsible for making mistakes by ignoring others within the family scope as regulated in Article 9 paragraph (1) jo. Article 49a of Law No. 23 of 2004 concerning the Elimination of Domestic Violence; sentence the defendant to 2 (two) months in prison [47].

The rejection of medical actions by parents of pediatric patients who cause physical suffering to children is also classified as illegal in the perspective of civil law (Article 1365 of the Civil Code). 
Rejection of medical actions that cause child suffering is contrary to the legal obligations of parents against children, as determined in Article 26 paragraph (1) of Law Number 35 Year 2014 concerning Amendments to Law Number 23 Year 2002 concerning Child Protection, as specified in Article 9 paragraph (1) of Law Number 23 Year 2004 concerning the Elimination of Domestic Violence. The Indonesian Child Protection Commission (KPAI) must have a legal position to sue parents of pediatric patients who refuse medical treatment that is very necessary for their children. KPAI was formed based on the sequence of Law No. 23 of 2002 concerning Child Protection and is tasked with increasing the effectiveness, maintaining and overseeing child protection.

\subsection{State Obligations in Child Protection}

Children as future generations, constantly, become the concern of the community at global and national levels. On the other hand, their mental and physical limitations and dependence on adults including parents position children in vulnerable situations. Children have the same rights as adults. Unfortunately, they cannot protect and defend their rights independently. Thus, it is natural that children become the priority subjects of international and national legal protection.

As mandated in the opening of 1945 Constitution of the Indonesian Republic, the state's goal is to prosper the people, to educate the nation's life, defense and security and to uphold justice. Every individual in Indonesia, wherever they are, will get protection of rights from the State, including the rights of children. Related to human rights, Welfare and prosperity functions are listed in Article 28A of the 1945 Constitution which states "Every person has the right to live and has the right to defend his life and life". Then, article 28B clause (2) of the 1945 Constitution of the Republic of Indonesia states, "Every child has the right of survival, growth and development, and is entitled to protection from violence and discrimination" [48].

In Indonesia, child protection is based on a few principles got from Pancasila, the 1945 Constitution and the Convention on the Rights of the Child which incorporates: non-discrimination, the best interests of children, the right to life, survival and development and respect childrens opinions [49]. Along these lines, each regulation and policy of the Indonesian government with respect to child protection must be guided by the principle of the the best interests of the child.

In the Tenth Part Chapter III of Law Number 39 Year 1999 concerning Human Rights with regard to the Rights of the Child, Article 52 paragraph (2) states that children's rights are human rights. For these rights, children are protected by law from the womb. The state is obliged to guarantee that Indonesian children are free from crime, discrimination and guarantees of child development and the right to education [50]. The state guarantees the protection and welfare of children through Law Number 23 of 2002 concerning Child Protection. Article 1 defines Child Protection as "all activities to guarantee and protect children and their rights, so that they can live, grow, develop, and participate optimally in accordance with human dignity and dignity, and receive protection from violence and discrimination".

\section{Conclusion}

Pediatric patients are incompetent in conducting therapeutic transactions. Thus, to refuse or approve medical treatment, it is carried out by parent as their competent close relative. Through legal process, parents of pediatric patients who refuse medical treatment which have fatal physical consequences can be prosecuted as criminal based on Law Number 35 Year 2014, concerning Amendments to Law Number 23 Year 2002 concerning Child Protection and Law Number 23 Year 2004 concerning the Elimination of Domestic Violence. In the aspect of civil law, the refusal is included in acts against the law if it opposing the rights of children. However, in Indonesia there are no specific rules that concretely regulate legal sanctions for parents of pediatric patients who refuse medical actions that result in physical suffering for their children. Based on the mandate of the 1945 Constitution and the Convention on the Rights of the Child, the state is obliged to provide legal protection towards rights based on the best interests of the child. Therefore, if legal vacuum 
related to child protection occured, the state must immediately formulate the law and implement it. To fully apply the right of children in receiving health services, the state needs to formulate strict and specific rules. So that rejection of medical actions that inaccordance with the best interests of the child principle can be prevented.

\section{Acknowledgments}

The author wishes to thank the Head of Universitas Muhammadiyah Malang and Head of Master of Law Study Program for providing a facility to join International Conference in ICILS $3^{\text {rd }}$ International Conference 2020 UNNES.

\section{References}

[1] Asyhadie, Z. (2017). Aspek-aspek hukum kesehatan di Indonesia. Depok: PT RajaGrafindo Persada.

[2] Budiono, H. (2006). Asas Keseimbangan bagi Hukum Perjanjian Indonesia (hal. 1-574).

hal. 1-574.Bandung: PT.Citra Aditya Bakti.

[3] Busro, A. (2018). Aspek Hukum Persetujuan Tindakan Medis (Inform Consent) Dalam Pelayanan Kesehatan. Law \& Justice Journal, 1(1), 1-18.

[4] Chazawi, A. (2010). Malpraktek Kedokteran, Tinjauan Norma dan Doktrin Hukum. Malang: Bayumedia Publishing.

[5] Dahlan, S. (2005). Hukum kesehatan rambu-rambu bagi profesi dokter. Semarang: Badan Penerbit Universitas Diponegoro.

[6] Elisa, F., Busro, A., \& Suharto, R. (2016). Kajian Hukum Informed Consent Pada Perjanjian Terapeutik Antara Dokter dan Pasien Dibawah Umur Berdasarkan Peraturan Menteri Kesehatan No. 290/MENKES/PER/III/2008 Tentang Persetujuan Tindakan Kedokteran. Diponegoro Law Review, 5(1), 1-11. Diambil dari http://www.ejournals1.undip.ac.id/index.php/dlr/

[7] Felenditi, D. (2009). Penegakan Otonomi Pasien Melalui Persetujuan Tindakan Medis (Informed Consent). Jurnal Biomedik, 1(1), 29-40.

[8] Guwandi, J. (2006). Informed Consent \& Informed Refusal (4 ed.). Jakarta: Fakultas Kedokteran Universitas Indonesia.

[9] Ibrahim, J. (2008). Teori \& Metodologi Penelitian Hukum Normatif, Malang. Bayumedia Publishing, cet. Keempat.

[10] Isfandiarie, A. (2006). Tanggung Jawab Hukum dan Saksi Bagi Dokter (hal. 57). hal. 57. Jakarta: Prestasi Pustaka.

[11] Koeswadji, H. H. (1998). Hukum Kedokteran: Studi Tentang Hubungan Hukum dalam mana Dokter Sebagai Salah Satu Pihak. Bandung: PT. Citra Aditya Bakti.

[12] Komalawati, V. (1999). Peranan Informed Consent dalam Transaksi Terapeutik. Bandung:

PT. Citra Aditya Bakti.

[13] Kurniawan, T. (2015). Peran Parlemen Dalam Perlindungan Anak. Aspirasi, 6(1), 37-51.

[14] Nasution, J. B. (2005). Hukum Kesehatan Pertanggungjawaban Dokter. Jakarta: Rineka Cipta.

[15] Penjelasan Undang-Undang Republik Indonesia Nomor 35 Tahun 2014 tentang Perubahan Atas Undang-Undang Nomor 23 Tahun 2002 tentang Perlindungan Anak.

[16] Putusan No. 113/Pid.B/2014/PN.Sbb Pengadilan Negeri Sumbawa Besar tanggal, 23 Juni 2014. , (2014).

[17] Rusyad, Z. (2018). Hukum Perlindungan Pasien. Malang: Setara Press.

[18] Santoso, M. I. E. (2017). Pertanggung Jawaban Perdata Malpraktik Dokter (1 ed.). Malang: MISYKAT Indonesia.

[19] Sastroasmoro, S. (2005). Masalah Etis dalam Proses Pengambilan Keputusan pada Praktik Pediatri. Sari Pediatri, 7(3), 125-131.

[20] Singal, A. (2017). Aspek Hukum Peran Pemerintah Melindungi Hak Anak Dalam Memperoleh Pelayanan Kesehatan. Jurnal Hukum Unsrat, 23(9), 38-52. 
[21] Siringoringo, V. M. P., Hendrawati, D., \& Suharto, R. (2017). Pengaturan Perlindungan Hukum Hak-Hak Pasien Dalam Peraturan Perundang-Undangan Tentang Kesehatan Di Indonesia. Diponegoro Law Journal, 6(2), 1-13.

[22] Subekti, T. (2011). Penafsiran Sistematis Terhadap Konsep "Setiap Anak" Berhak Untuk Mengetahui Orang Tuanya Dalam Pasal 1 Ayat (1) Undang Undang No. 23 Tahun 2002 Tentang Perlindungan Anak. Jurnal Dinamika Hukum, 11(Edsus). https://doi.org/10.20884/1.jdh.2011.11.edsus.266

[23] Sudrajat, T. (2011). Perlindungan Hukum Terhadap Hak Anak Sebagai Hak Asasi Manusia Dalam Perspektif Sistem Hukum Keluarga di Indonesia. Kanun Jurnal Ilmu Hukum, XIII(54), 111-132.

[24] Suganda, M. W. (2017). Hukum Kedokteran (1 ed.). Bandung: Alfabeta.

[25] Suprapti Samil, R. (2001). Etika kedokteran islam. Jakarta: Yayasan Bina Pustaka Sarwono Prawirodihardjo.

[26] Taufiq, M. (2011). Perspektif Yuridis Tanggung Jawab Dokter Terhadap Rahasia Medis Pasien HIV/AIDS (Studi di Rumah Sakit Umum Daerah Banyumas). Jurnal Dinamika Hukum, 11(3), 424-438.

[27] Wardani, Y. K., \& Fakih, M. (2017). Praktik Penerapan Peraturan Menteri Kesehatan Nomor 290 Tahun 2008 Tentang Persetujuan Tindakan Kedokteran (Informed Consent) Pada Pelayanan Gawat Darurat di Rumah Sakit. Jurnal Hukum Replik, 5(2), 112-127.

[28] Wicaksana, I. D. (2019). Tinjauan Terhadap Dokter Yang Menangani Pasien Gawat Darurat Tanpa Menggunakan Informed Consent. Jurnal Privat Law, VII(1), 150-155.

[29] Zulhasmar, \& Eric. (2008). Implikasi Hukum Penolakan Tindakan Medik. Lex Jurnalica, $5(2), 83-111$. 